\title{
Risk Mapping of Bogie S2HD-9C Production Process that Take Effect on Production Fulfillment at PT. Barata Indonesia (Persero)
}

\author{
Faza Yoshio Susanto, Naning Aranti Wessiani, ST, MM \\ Department of Industrial Engineering, Faculty of Industrial Technology, Institut Teknologi Sepuluh \\ Nopember (ITS) \\ Jl. Arief Rahman Hakim, Surabaya 60111 Indonesia \\ e-mail:wessiani@ie.its.ac.id
}

\begin{abstract}
PT Barata Indonesia (Persero) is one of leading metal works company in Indonesia. It has 3 main business line which are engineering procurement and construction (EPC), industrial tools manufacturing, and foundry. As the company's strategic objective in delivering quality product and service to the customer, PT Barata Indonesia should maintain their production process properly. One of the featured product of PT Barata Indonesia is bogie. The production process of bogie shows a fluctuative delivery fulfillment. It can be proved by the contract amendment information. Risk management can be used as the method to manage risk inside the production process of bogie. Therefore, this research is aimed to identify risks that may occur from each activities of bogie S2HD-9C's production process. The risk identification is done by using fault tree analysis method in order to determine the root cause of each activity performed. The risk evaluation is done by using FMEA method which can classify the effects of failure based on the severity and occurrence of failure. Then continue to the risk mapping and risk mitigation determination for bogie S2HD-9C's production process. Loss that caused by the emergence of risk also determined using value at risk method. Moreover, risk profile dashboard will be provided as the tools in managing risk.
\end{abstract}

Keywords-Fault Tree Analysis (FTA), FMEA, Production Process, Risk Dashboard, Risk Management, Risk Map, Risk Mitigation, Value at Risk

\section{INTRODUCTION}

PT Barata Indonesia is one of the government company in Indonesia which has 3 main business line. There are, engineering procurement and construction (EPC), industrial tools manufacturing, and foundry (PT. Barata Indonesia, 2013). Some products of PT Barata Indonesia are, bogie, mill roll, pipeline, road rollers, storage tank, and also ball tank.

PT Barata Indonesia is a leading bogie supplier in Indonesia with $100 \%$ local demand fulfillment. Moreover, PT Barata Indonesia penetrated United States market with 1,500 bogie delivered since 2012. Bogie's supply both local and worldwide shows a positive trend. This condition forced PT Barata Indonesia to maintain the commitments to give a competitive service in terms of quality, price, and delivery (PT. Barata Indonesia, 2013).

As the company's strategic objective in delivering quality product and service to the customer, PT Barata Indonesia should maintain their production process properly. Moreover, quality and service of product should be addressed as company's competitive advantage in order to compete in the global market. Competitive advantage that brings higher income to the company can be fulfilled with organization of production, higher application, and as low as possible production costs (Wang, Lin, \& Chu, 2011).

In fact, PT Barata Indonesia currently facing some obstacles regarding to the company's strategic objective. The production process of PT Barata Indonesia cannot achieve zero defect production. Although the order of product is the same, the completion of product still not good enough. It can be proved by the number of contract amendment information. Both machineries used and people also made some contribution to the production condition. For example, some of the machines inside the workshop needs several preventive maintenance to maintain its condition. Unfortunately, the worker who has responsibility to maintain the machine were not doing their job. Because of that, some of the machines used broken down. Moreover, the equipments used for the production of bogie is less sophisticated and the production planning is not good enough. So, that condition make the probability of delivery lateness become higher.

This condition makes the company have to reschedule their completion date of product and make some amendment for the contracts with the customer. In the middle of 2015, PT Barata Indonesia have established commercial and risk bureau whom responsible to company's risk management. Unfortunately, there were no risk assessment performed on bogie S2HD-9C's production process. Usually the production department makes a small notes for every defects occurred on each batch of production. But there were no further analysis or assessment in order to handle any possibilities of risk.

Risk might be a driver of strategic decisions because of its uncertainty (Institute of Risk Management, 2010). The strategic decisions made by a company will determine the achievement of their strategic objectives in the future. PT Barata Indonesia need to understand the risk that embedded inside their company in order to achieve their objectives. Risk management can be used as the method to understand and anticipate risk inside the company. The focus of risk management is the assessment of significant risks and the implementation of suitable risk treatments (Institute of Risk Management, 2010). By implementing risk management PT Barata Indonesia will be 
able to increase the probability of achieving objectives, improve minimize losses, and prevent the risks to be occurred again in the future.

Based on previous explanation, this research is aimed to identify risks that may occur from each activities of bogie S2HD-9C's production process. The risk identification is done by using fault tree analysis method in order to determine the root cause of each activity performed. The risk evaluation is done by using FMEA method which can classify the effects of failure based on the severity and occurrence of failure. Then continue to the risk mapping and risk mitigation determination for bogie S2HD-9C's production process. In order to make the risk monitoring activity easier, this research will provide risk profile dashboard as one of the research output by using macro excel software. With the output of this research, PT Barata Indonesia are expected to minimize the risk that occurred in bogie S2HD-9C's production process

\section{RESEARCH METHODOLOGY}

\section{A. Brainstorming and Initial Identification Stage}

Initial identification stage consists of brainstorming and identification of existing condition in workshop 1 PT Barata Indonesia, accompanied by responsible division in workshop 1 which is Industry Division. So the objective of this research can be obtained which is developing the risk mapping of Bogie S2HD-9C's production process.

1. Data Collection Stage

Data collection stage is done by conducting interviews, reviewing company's data, and also questionnaire. All of the data obtained will be used as the input of risk mapping construction of Bogie S2HD-9C's production process

2. Data Processing Stage

The data processing stage will be done through the completion of several process such as, questionnaire validation, risk evaluation by using FMEA method, risk mapping, risk mitigation, value at risk, and develop risk profile dashboard.

3. Analysis Stage

In this stage, the analysis and data interpretation activity will be done. This stage will be based on the result of data processing stage. Several data analysis that will be conducted are, production process analysis, risk analysis, risk assessment analysis, risk mapping analysis, mitigation analysis, dashboard analysis, and value at risk analysis.

4. Conclusion Stage

In this stage, the conclusion and suggestion will be determined. The given conclusion and suggestion will be based on data analysis and interpretation which has been done before. Conclusion will answer the objectives of research and the suggestion will be given for the company and further research.

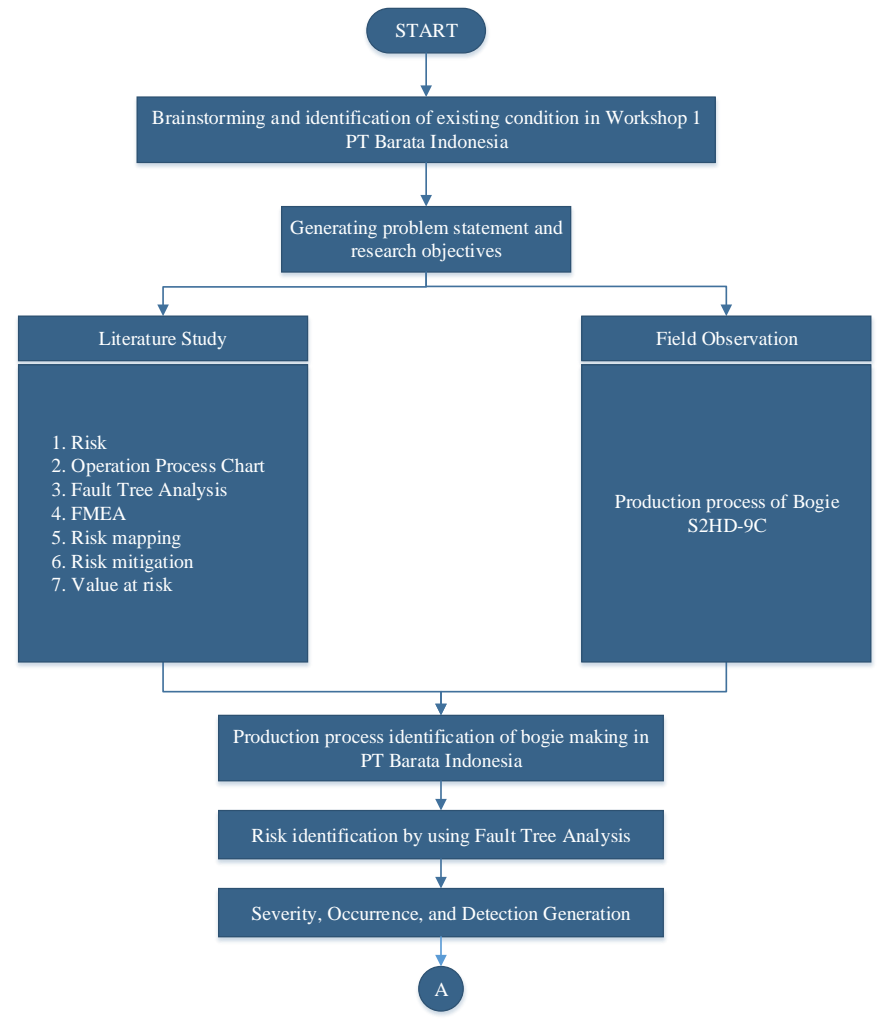

Figure 1. Flowchart of Research Methodology

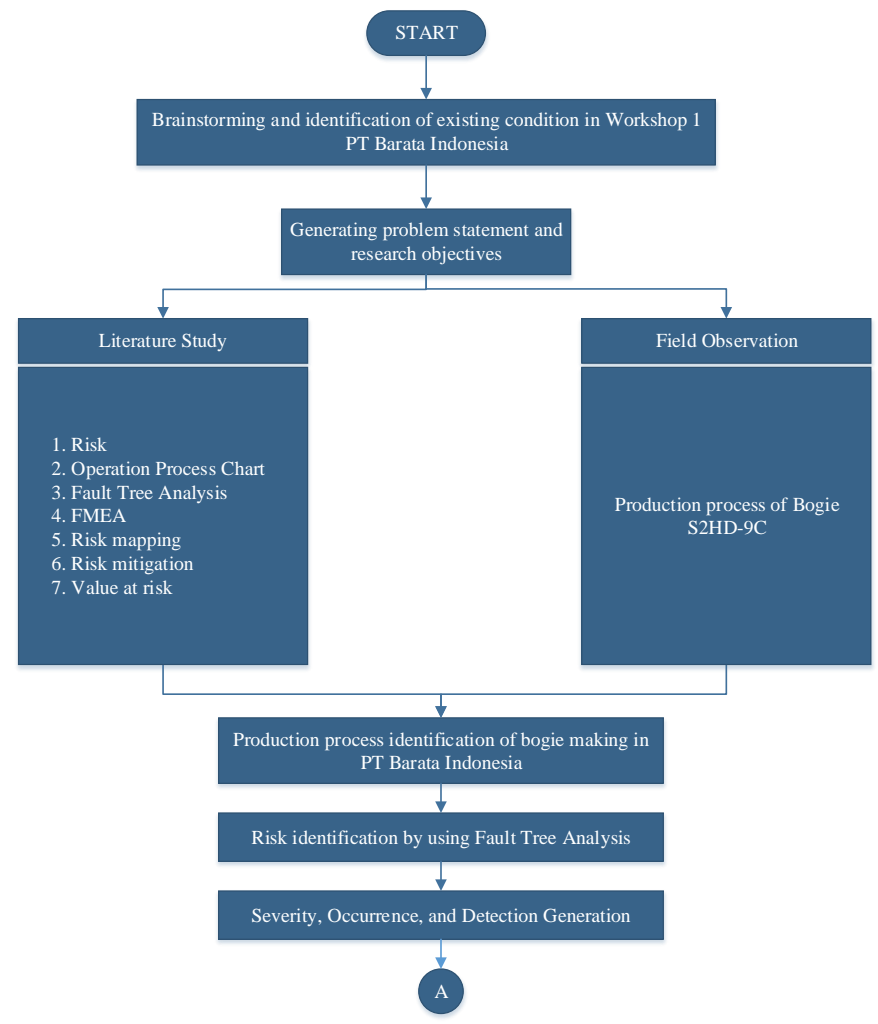

Figure 1. Flowchart of Research Methodology 


\section{DATA COLLECTION AND PROCESSING}

\section{A. Production Process Identification}

The first stage that need to be done is determine the production process of Bogie S2HD-9C. The production process will be determined using Operation Process Chart (OPC) method.

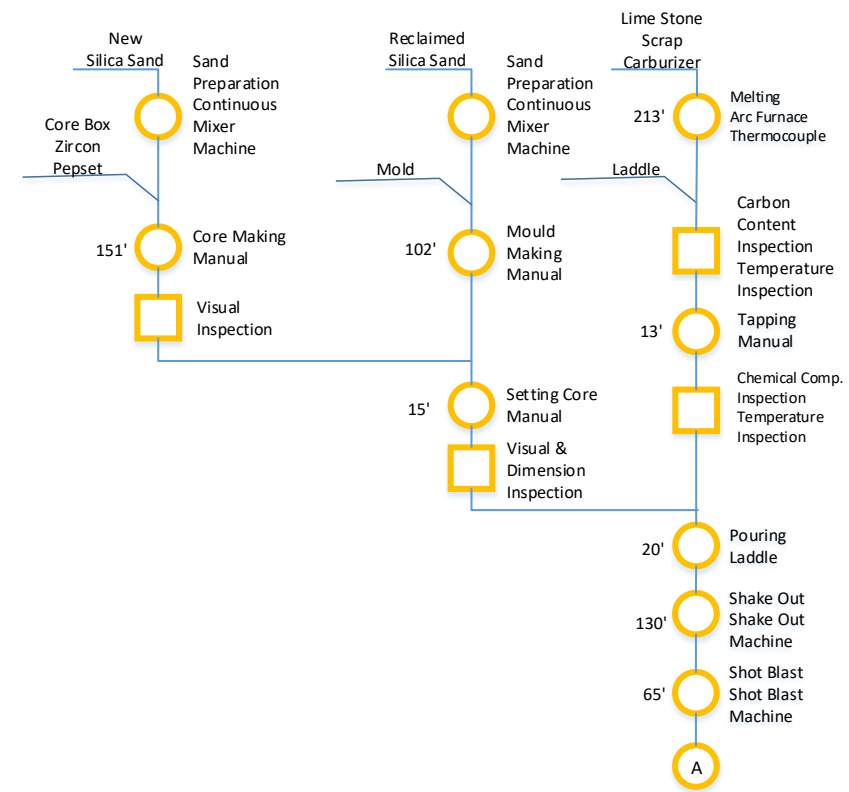

Figure 2. Production Process Identification

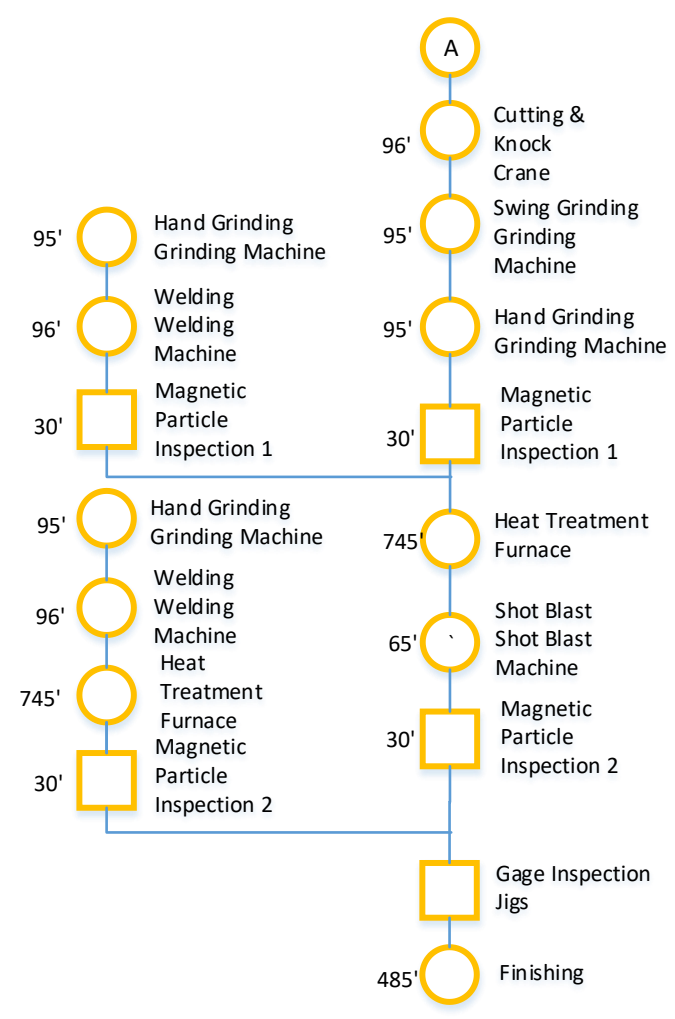

\section{B. Risk Identification and Assessment}

Risk identification process will be done by using Fault Tree Analysis (FTA) method. The risk will be identified from each activities performed. Then each risk will be assessed by using FMEA method.

Table 1. Risk Identification

\begin{tabular}{clc}
\hline \hline Risk Code & \multicolumn{1}{c}{ Risk } & RPN \\
\hline R1 & Broken Compressor & 8 \\
R2 & The pattern is not completely cleaned & 16 \\
R4 & Broken Pump & 120 \\
R5 & Improper mixing & 6 \\
R6 & Broken Furnace & 32 \\
R7 & Broken Compressor & 24 \\
R8 & The pattern is not completely cleaned & 8 \\
R9 & Broken Pump & 12 \\
R10 & Improper mixing & 168 \\
R11 & Broken corebox & 6 \\
R12 & Broken core & 12 \\
\hline \hline
\end{tabular}

Figure 2. Production Process Identification (con't) 
JURNAL TEKNIK ITS Vol. 5, No. 2, (2016) ISSN: 2337-3539 (2301-9271 Print)

Table 1. Risk Identification (con't)

\begin{tabular}{|c|c|c|}
\hline $\begin{array}{l}\text { Risk } \\
\text { Code }\end{array}$ & Risk & RPN \\
\hline $\mathrm{R} 13$ & Bad coating & 48 \\
\hline $\mathrm{R} 14$ & Incomplete core & 6 \\
\hline R15 & Broken core & 10 \\
\hline $\mathrm{R} 16$ & $\begin{array}{l}\text { The core and parting lines is not } \\
\text { completely cleaned }\end{array}$ & 8 \\
\hline $\mathrm{R} 17$ & Loose material left behind & 90 \\
\hline R18 & Broken core & 4 \\
\hline R19 & Raw material doesn't meet standard & 8 \\
\hline $\mathrm{R} 20$ & Broken thermocouple & 4 \\
\hline $\mathrm{R} 21$ & Broken Furnace & 80 \\
\hline $\mathrm{R} 22$ & Improper chemical composition & 8 \\
\hline $\mathrm{R} 23$ & Improper chemical composition & 24 \\
\hline $\mathrm{R} 24$ & Improper ladle setting & 20 \\
\hline $\mathrm{R} 25$ & Temperature higher than standard & 6 \\
\hline $\mathrm{R} 26$ & Temperature higher than standard & 16 \\
\hline $\mathrm{R} 27$ & Pouring time too long & 6 \\
\hline $\mathrm{R} 28$ & Broken belt conveyor & 112 \\
\hline R29 & $\begin{array}{l}\text { The casting was shake when the } \\
\text { temperature is high }\end{array}$ & 12 \\
\hline R30 & Malfunctioned crane & 96 \\
\hline $\mathrm{R} 31$ & Casting cannot be pulled out & 30 \\
\hline $\mathrm{R} 32$ & Broken belt conveyor & 112 \\
\hline $\mathrm{R} 33$ & $\begin{array}{l}\text { The casting was shake when the } \\
\text { temperature is high }\end{array}$ & 12 \\
\hline R34 & Malfunctioned crane & 96 \\
\hline $\mathrm{R} 35$ & Casting cannot be pulled out & 12 \\
\hline $\mathrm{R} 36$ & Malfunctioned crane & 30 \\
\hline $\mathrm{R} 37$ & Setting need a longer time to finish & 16 \\
\hline $\mathrm{R} 38$ & Malfunctioned impeller & 112 \\
\hline $\mathrm{R} 39$ & The casting still has a rough surface & 36 \\
\hline $\mathrm{R} 40$ & Setting need a longer time to finish & 4 \\
\hline R41 & Cutting result doesn't meet standard & 12 \\
\hline
\end{tabular}

Table 1. Risk Identification (con't)

\begin{tabular}{|c|c|c|}
\hline Risk Code & Risk & RPN \\
\hline R42 & Setting need a longer time to finish & 4 \\
\hline R43 & Line full & 50 \\
\hline R44 & The casting need a lot of grinding & 48 \\
\hline R45 & The casting still need to be processed & 40 \\
\hline R46 & The fluid is not applied well & 24 \\
\hline R47 & Improper inspection & 48 \\
\hline R48 & Broken MPI tools & 48 \\
\hline R49 & Zone 1 defect discovered & 192 \\
\hline R50 & Setting need a longer time to finish & 8 \\
\hline R51 & Line full & 40 \\
\hline R52 & Casting need a lot of welding & 40 \\
\hline R53 & The casting still need to be processed & 8 \\
\hline R54 & Broken furnace & 16 \\
\hline R55 & Undisciplined method & 12 \\
\hline R56 & Thermocouple broken & 16 \\
\hline R57 & $\begin{array}{l}\text { The casting cannot be pulled out from the } \\
\text { machine }\end{array}$ & 12 \\
\hline R58 & The casting need a longer time to cool down & 4 \\
\hline R59 & Casting need heat treatment process & 48 \\
\hline R60 & The clamp cannot hold the work piece & 6 \\
\hline R61 & Line full & 60 \\
\hline R62 & Broken CNC machine & 48 \\
\hline R63 & work piece cannot meet the dimensional standard & 12 \\
\hline R64 & Setting need a longer time to finish & 8 \\
\hline R65 & The casting dimension doesn't meet requirement & 8 \\
\hline R66 & Nuts and bolts cannot be set & 8 \\
\hline R67 & Wrong arrangement of product & 12 \\
\hline
\end{tabular}




\section{Risk Mapping}

After the risk already identified and assessed by using FMEA method, then all of the risk will be plotted into risk map in order to determine the classification of risk based on its category. There are three categories such as, high risk, medium risk, and low risk.

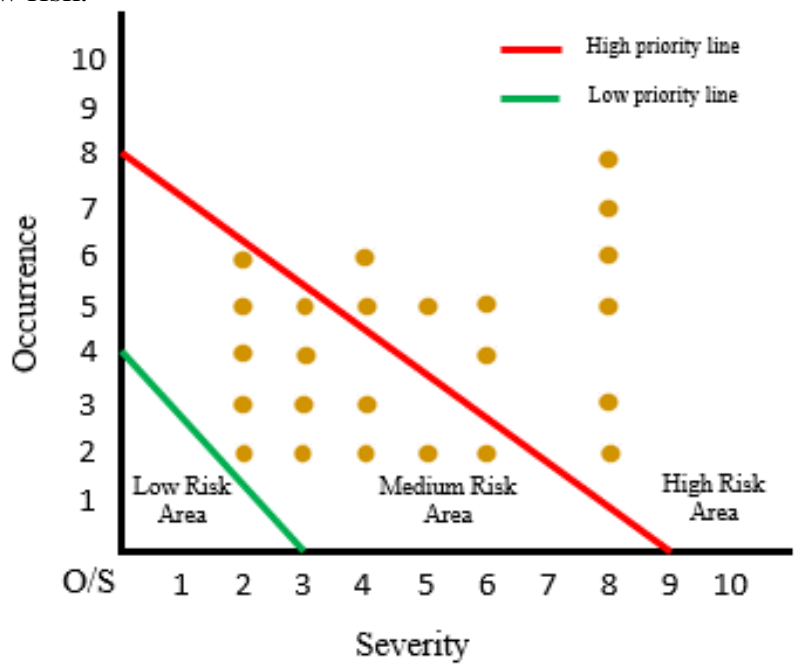

Figure 3. Risk Map

The result of risk map is 45 medium risk and 22 high risk. Next, the risk with category high risk will get a corrective action or mitigation in order to manage the risk

\section{Risk Mitigation}

The risk mitigation is the way to manage the risk in order to reduce the probability of risk occurred. There are four classification of risk mitigation such as, avoid, transfer, mitigate, and accept. There are 15 avoid risk, 4 transfer risk, 13 mitigate risk, and 13 accept risk.

\section{E. Value at Risk}

Value at Risk is the way to develop the loss caused by the emergence of risk. In the calculation process, there will be several data needed such as, lateness time data, repair cost data, and also electricity cost data. Using the $95 \%$ confidence interval, the probability of loss will be obtained.

Table 2. Simulation Result

\begin{tabular}{lll}
\hline \hline Code & \multicolumn{1}{c}{ Risk } & \multicolumn{1}{c}{ Loss } \\
\hline R13 & Bad coating & VaR @ Rp 429,778 \\
R17 & Loose material left behind & VaR @ Rp 156,224 \\
R26 & Temperature higher than standard & VaR @ Rp 193,200 \\
R43 & Line full & VaR @ Rp 260,912 \\
R44 & The casting need a lot of grinding & VaR @ Rp 216,247 \\
R45 & The casting still need to be processed & VaR @ Rp 55,805 \\
R47 & Improper inspection & VaR @ Rp 215,891 \\
R49 & Zone 1 defect discovered & VaR @ Rp 461,706 \\
R51 & Line full & VaR @ Rp 482,307 \\
R52 & Casting need a lot of welding & VaR @ Rp 452,010 \\
\hline \hline
\end{tabular}

Table 2. Simulation Result (con't)

\begin{tabular}{lll}
\hline \hline Code & \multicolumn{1}{c}{ Risk } & \multicolumn{1}{c}{ Loss } \\
\hline R59 & Casting need heat treatment process & VaR @ Rp 519,998 \\
R61 & Line full & VaR @ Rp 1,038,504 \\
\hline \hline
\end{tabular}

\section{F. Risk Profile Dashboard}

After the loss calculation already performed, the risk profile dashboard will be constructed. Risk profile dashboard is aimed to help PT Barata Indonesia to manage the risk embedded in production process of Bogie. There are several functions that can be accessed through the dashboard such as, risk database, risk assessment, risk mitigation, risk updating, and loss calculation. The construction of risk profile dashboard will use Microsoft Excel Software.

\section{CONCLUSION/SUMMARY}

There are 67 identified risk of bogie S2HD-9C production process. First thing to do is conducting risk assessment by using FMEA method. Then each risk will be evaluated based on the RPN number. The highest RPN number was obtained from R49 which is zone 1 defect discovered with 192 and lowest RPN number was obtained from R58 which is casting need a longer time to cooldown with 4 . There are 22 risk which categorized as high risk and the rest of the risk are categorized as medium risk. Risk mitigation is addressed to the high category risk. Based on the mitigation effort determination proportion, there are 15 avoid effort, 13 mitigate effort, 13 accept effort, and 4 transfer effort.

Value at Risk is done by using variance-covariance method. There are 12 high risk that calculated from 21 high risk identified. Based on the calculation result the highest loss caused by the emergence of risk occurred in R61 which is line

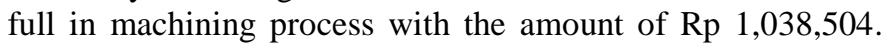
Meanwhile, the lowest value of loss caused by the emergence of risk occurred in R45 which is casting still need to be processed in grinding process with $\mathrm{Rp} 55,805$.

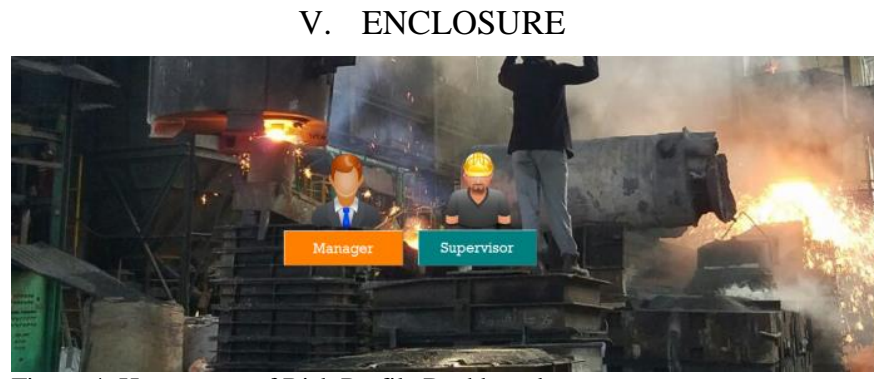

Figure 4. Home page of Risk Profile Dashboard 


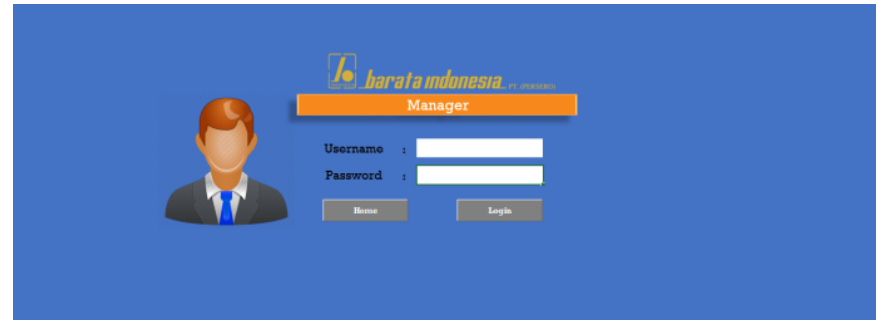

Figure 5. Manager Login

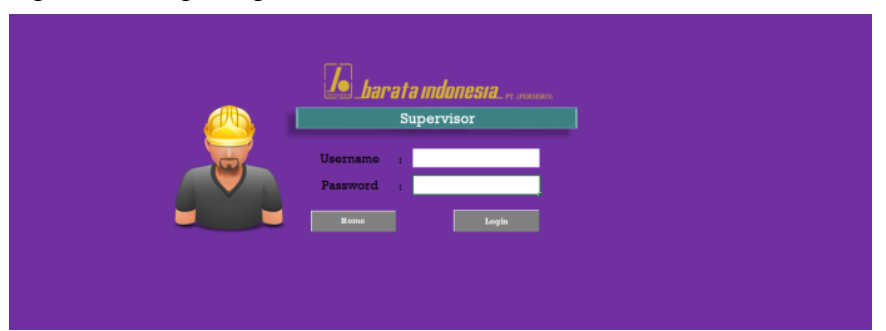

Figure 6. Supervisor Login

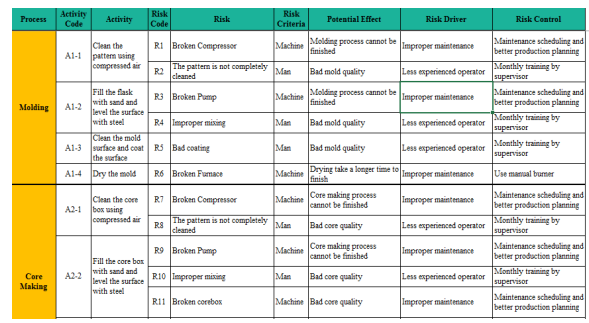

Figure 7. Risk Database

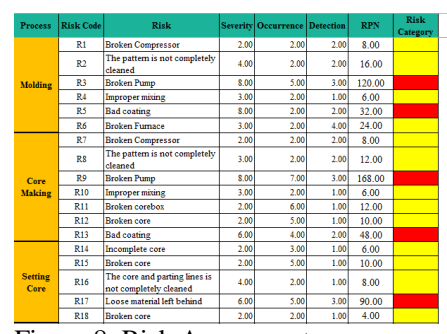

Figure 8. Risk Assessment

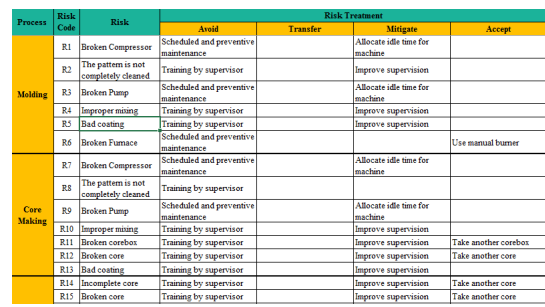

Figure 9. Risk Mitigation

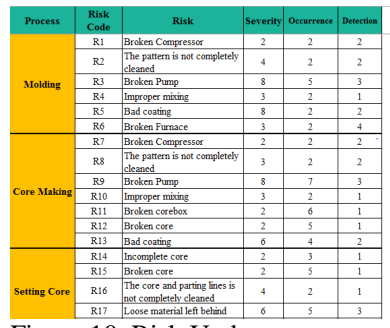

Figure 10. Risk Update

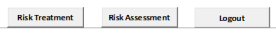

$$
\text { Risk Dotabse }\{\text { Risis Mitization }\} \text { Legout }
$$

W.

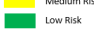

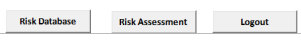

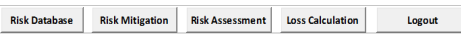

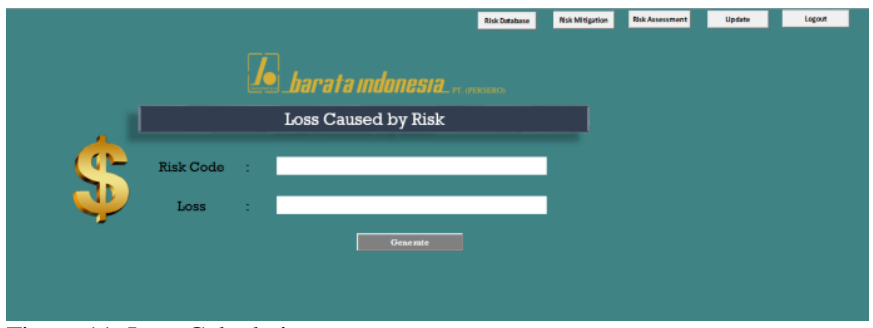

Figure 11. Loss Calculation 


\section{Table 3. Risk Mitigation}

\begin{tabular}{|c|c|c|c|c|c|}
\hline \multirow{2}{*}{$\begin{array}{l}\text { Risk } \\
\text { Code }\end{array}$} & \multirow{2}{*}{ Risk } & \multicolumn{4}{|c|}{ Risk Treatment } \\
\hline & & Avoid & Transfer & Mitigate & Accept \\
\hline R3 & Broken Pump & $\begin{array}{l}\text { Scheduled and preventive } \\
\text { maintenance }\end{array}$ & - & $\begin{array}{l}\text { Allocate idle time for machine; } \\
\text { provide spare part }\end{array}$ & - \\
\hline R5 & Bad coating & Training by supervisor & - & Improve supervision & - \\
\hline R9 & Broken Pump & $\begin{array}{l}\text { Scheduled and preventive } \\
\text { maintenance }\end{array}$ & - & $\begin{array}{l}\text { Allocate idle time for machine; } \\
\text { provide spare part }\end{array}$ & - \\
\hline $\mathrm{R} 13$ & Bad coating & Training by supervisor & - & Improve supervision & - \\
\hline $\mathrm{R} 17$ & Loose material left behind & Training by supervisor & - & Improve supervision & - \\
\hline $\mathrm{R} 21$ & Broken Furnace & $\begin{array}{l}\text { Scheduled and preventive } \\
\text { maintenance }\end{array}$ & - & $\begin{array}{l}\text { Allocate idle time for machine; } \\
\text { provide spare part }\end{array}$ & - \\
\hline $\mathrm{R} 26$ & $\begin{array}{l}\text { Temperature higher than } \\
\text { standard }\end{array}$ & $\begin{array}{l}\text { Check the temperature before } \\
\text { pouring }\end{array}$ & - & - & Repair \\
\hline $\mathrm{R} 28$ & Broken Belt Conveyor & $\begin{array}{l}\text { Scheduled and preventive } \\
\text { maintenance }\end{array}$ & - & $\begin{array}{l}\text { Allocate idle time for machine; } \\
\text { provide spare part }\end{array}$ & - \\
\hline $\mathrm{R} 30$ & Malfunctioned crane & $\begin{array}{l}\text { Scheduled and preventive } \\
\text { maintenance }\end{array}$ & - & $\begin{array}{l}\text { Allocate idle time for machine; } \\
\text { provide spare part }\end{array}$ & Use another crane \\
\hline $\mathrm{R} 32$ & Broken Belt Conveyor & $\begin{array}{l}\text { Scheduled and preventive } \\
\text { maintenance }\end{array}$ & - & - & - \\
\hline $\mathrm{R} 34$ & Malfunctioned crane & $\begin{array}{l}\text { Scheduled and preventive } \\
\text { maintenance }\end{array}$ & - & $\begin{array}{l}\text { Allocate idle time for machine; } \\
\text { provide spare part }\end{array}$ & Use another crane \\
\hline $\mathrm{R} 38$ & Malfunctioned impeller & $\begin{array}{l}\text { Scheduled and preventive } \\
\text { maintenance }\end{array}$ & - & $\begin{array}{l}\text { Allocate idle time for machine; } \\
\text { provide spare part }\end{array}$ & - \\
\hline $\mathrm{R} 43$ & Line full & - & $\begin{array}{l}\text { Employ worker from another } \\
\text { station }\end{array}$ & - & Proceed to next process \\
\hline R44 & $\begin{array}{l}\text { The casting need a lot of } \\
\text { grinding }\end{array}$ & - & $\begin{array}{l}\text { Employ worker from another } \\
\text { station }\end{array}$ & - & Hold the product \\
\hline $\mathrm{R} 45$ & $\begin{array}{l}\text { The casting still need to } \\
\text { be processed }\end{array}$ & - & - & - & Repeat grinding \\
\hline
\end{tabular}


Table 3. Risk Mitigation (con't)

\begin{tabular}{|c|c|c|c|c|c|}
\hline \multirow{2}{*}{$\begin{array}{l}\text { Risk } \\
\text { Code }\end{array}$} & \multirow{2}{*}{ Risk } & \multicolumn{4}{|c|}{ Risk Treatment } \\
\hline & & Avoid & Transfer & Mitigate & Accept \\
\hline $\mathrm{R} 47$ & Improper inspection & Training by supervisor & - & Improve supervision & - \\
\hline $\mathrm{R} 48$ & Broken MPI tools & $\begin{array}{l}\text { Scheduled and preventive } \\
\text { maintenance }\end{array}$ & - & Provide spare part & Use available mpi machine \\
\hline $\mathrm{R} 49$ & Zone 1 defect discovered & - & - & - & Repair \\
\hline $\mathrm{R} 51$ & Line full & - & $\begin{array}{l}\text { Employ worker from another } \\
\text { station }\end{array}$ & - & Adding operator \\
\hline $\mathrm{R} 52$ & $\begin{array}{l}\text { Casting need a lot of } \\
\text { welding }\end{array}$ & - & $\begin{array}{l}\text { Employ worker from another } \\
\text { station }\end{array}$ & - & Hold the product \\
\hline R59 & $\begin{array}{l}\text { Casting need heat } \\
\text { treatment process }\end{array}$ & - & - & - & Repair \\
\hline $\mathrm{R} 61$ & Line full & - & - & - & $\begin{array}{l}\text { Extra shift for machining } \\
\text { process }\end{array}$ \\
\hline $\mathrm{R} 62$ & Broken CNC machine & $\begin{array}{l}\text { Scheduled and preventive } \\
\text { maintenance }\end{array}$ & - & Provide spare part & Use available machine \\
\hline
\end{tabular}




\section{DAFTAR PUSTAKA}

[1] PT. Barata Indonesia, "PT. Barata Indonesia," 2013. [Online]. Available: www.barata.co.id.

[2] Institute of Risk Management, "A structured approach to Enterprise Risk Management (ERM) and the requirements of ISO 31000," Institute of Risk Management, London, 2010.

[3] P. S. A. R. Angga Adiperdana, "Analisis Value at Risk Menggunakan Metode Extreme Value Theory Generalized Pareto DIstribution dengan Kombinasi Algoritma Meboot dan Teori Samad-Khan (Studi Kasus PT. X)," Industrial Engineering Department ITS, Surabaya, 2010.

[4] M. Anityasari and N. A. Wessiani, Analisa Kelayakan Usaha, Surabaya: Guna Widya, 2011.

[5] C. S. Carlson, Effective FMEAs: Achieving Safe, Reliable, and Economical Products and Processes using Failure Mode and Effects Analysis, John Wiley \& Sons, 2012.

[6] C. S. Carlson, "Understanding and Applying the Fundamentals of FMEAs," in Annual Reliability and Maintainability Symposium, Tucson, 2014.

[7] Z. Fabók, "Fault Tree Analysis," 9 September 2013. [Online]. Available: http://zsoltfabok.com/blog/2013/09/fault-tree-analysis/.

[8] A. M. Haifani, "Manajemen Resiko Bencana Gempa Bumi (Studi Kasus Gempa Bumi Yogyakarta 27 Mei 2006)," in Seminar Nasional IV SDM Teknologi Nuklir, Yogyakarta, 2008.

[9] G. Monahan, Enterprise Risk Management: A Methodology for Achieving Strategic Objectives, Canada: John Wiley \& Sons, Inc., 2008.

[10] S. O. Sarwoko, "Designing Fuzzy FMEA Risk Management at Production Department PT. Charoen Pokphand Tbk - Poultry Feed Krian, Sidoarjo," Institut Teknologi Sepuluh Nopember, Surabaya, 2015.

[11] N. R. Utami, "Penyusunan Peta Risiko dalam Upaya Pengembangan Risiko pada PT. Telkomsel," Institut Teknologi Sepuluh Nopember, Surabaya, 2014.

[12] W.-C. Wang, C.-H. Lin and Y.-C. Chu, "Types of Competitive Advantage and Analysis," International Journal of Business and Management, pp. 100-104, 2011.

[13] Chrysler Corporation, Ford Motor Company, General Motors Corporation, Potential Failure Mode and Effects Analysis (FMEA) Reference Manual, Automotive Industry Action Group, 1993.

[14] D. Hillson, S. Grimaldi and C. Rafele, "Managing Project Risk Using a Cross Risk Breakdown Matrix," Risk Management, pp. 61-76, 2006.

[15] H. R. A. Nugroho, "Reduksi Waste dan Peningkatan Kualitas pada Proses Produksi Roll Gilingan Tebu dengan Pendekatan Metodologi Lean Six Sigma (Studi Kasus : PT Barata Indonesia, Gresik)," Institut Teknologi Sepuluh Nopember, Surabaya, 2014.
[16] D. R. Pramudita, "Perancangan dan Pengukuran Kinerja Lingkungan dengan Pendekatan Integrated Environment Performance Measurement System (IEPMS) di PT Barata Indonesia," Institut Teknologi Sepuluh Nopember, Surabaya, 2014.

[17] International Organization for Standardization, "ISO 31000:2009 (en)," 2009. [Online]. Available: https://www.iso.org/obp/ui/\#iso:std:iso:31000:ed1:v1:en. 